\title{
Comparative study between the effects of hyaluronic acid and acid galactan purified from eggs of the mollusk Pomacea $s p$ in wound healing ${ }^{1}$
}

\author{
Ana Katarina Menezes da $\mathrm{Cruz}^{2}$, Wogelsanger Oliveira Pereira ${ }^{2}$, Elizeu Antunes dos Santos ${ }^{2}$, Maria Goretti Freire \\ Carvalho $^{3}$,Aldo da Cunha Medeiros ${ }^{4}$, Fernanda Wanderley de Oliveira $^{2}$
}

\begin{abstract}
Cruz AKM, Pereira WO, Santos EA, Carvalho MGF, Medeiros AC, Oliveira FW. Comparative study between the effects of hyaluronic acid and acid galactan purified from eggs of the mollusk Pomacea sp in wound healing. Acta Cir Bras [serial online] 2004 Jan-Feb;19(1). Available from URL: http://www.scielo.br/acb.
\end{abstract}

\begin{abstract}
Purpose: To compare the effect of hyaluronic acid (HA) and of AG on the healing of intestine wounds. Methods: The semi-purified extract of the eggs of the mollusc was obtained by fractionation with ammonium sulfate and purification for ion-exchange chromatography. The obtained galactans were eluted in water (neutral galactan) and in 0.1 and $0.2 \mathrm{M} \mathrm{NaCl}$ (acidic galactans). The in vivo study was performed with 45 "Wistar" rats, separated in three groups $(\mathrm{n}=15)$. Solutions containing HA $1 \%$, GA $1 \%$ or saline solution $0,9 \%$, was placed topically on the sutures of wounds in the small intestine of the rats. After 05, 10 and 21 days the animals were sacrificed and biopsy of the healing tissue was done. Results: The hystologic grading was more significant for HA and AG groups when compared to the group C. AG stimulated the appearance of macrophages, giant cells and increase in the concentration of collagen in the area of the wound when compared to HA. Conclusion: The topical use of GA in intestinal wounds promoted the anticipation of events that are important in the wound healing.
\end{abstract}

KEY WORDS - Acid galactan. Hyaluronic acid. Pomacea sp. Glycosaminoglycans.

\section{Introduction}

Hyaluronic acid (HA) is the most basic form of glycosaminoglycan. HA is a linear polysaccharide, negatively charged, viscous, non-sulphated, and has a high molecular weight $\left(10^{4}\right.$ to $\left.10^{7}\right)$. It consists of repeating disaccharide units of $\mathrm{N}$ acetylglucosamine and glucuronic acid linked by $b(1,4)$ and $b(1,3)$ glycosidic linkages, respectively ${ }^{1}$. HA is widely distributed in vertebrates (mainly humans), and invertebrates. HA is involved in several cellular functions, including cell proliferation ${ }^{2}$, cell locomotion $^{3}$, and interactions with leukocytes ${ }^{4}$. HA is used clinically the treatment of joint disease ${ }^{5}$, in ophthalmic surgical devices ${ }^{6}$, and some studies have suggested benefits of its application in wound healing ${ }^{7}$.

In vertebrates $\mathrm{HA}$ is the predominant glycosaminoglycan at the beginning of morphogenesis. This coincides with the migration of the mesenchymal cells. Studies have demonstrated that HA is then replaced by condroitin 6-sulfate (probably synthetized by the mesenchymal cells), which becomes the main glycosaminoglycans ${ }^{8}$.

These studies were extended to invertebrates using the mollusc Pomacea $s p$ as a model. The results show the appearance of a non-sulfated neutral and acidic galactan at about day 5 , coinciding with the beginning of morphogenesis. This compound reaches its maximum concentration by day 7 and progressively decreases until day 12 with a concommitant appearence of condroitin sulfate $^{9}$. There are two waves of condroitin sulfate concentration - one peak at day 9 and another at day 12. The appearence of heparan sulfate by day 10 coincides with the cytodifferentiation stage. No HA have been demonstrated in the eggs of this mollusc. Analyzed the sequence of emergence of the polysaccharides with the histologic the findings that an acidic galactan is synthetized by the eggs during morphogenesis and of GAGS with the cytodifferentiation ${ }^{10}$.

Considering that $\mathrm{HA}$ is not found in the eggs of the mollusc, and that AG is synthesized during morphogenesis, in mammals, AG maybe substituting for the function of HA

1. Article from the Department of Biochemistry and Department of Surgery, Federal University of Rio Grande do Norte (UFRN), Natal, Brazil.

2. Master, Department of Biochemistry, UFRN-Natal.

3. Doctor, Department of Pathology, UFRN-Natal.

4. Professor, Doctor, Chief, Experimental Surgery Nucleous, UFRN-Natal. 
in the mollusc. Thus, there is a strong parallel between the embryonic development of mammals and molluscs. An acidic environment is provided by $\mathrm{HA}$ or $\mathrm{AG}$ at the beginning of morphogenesis, favoring the migration of mesenchymal cells ${ }^{8}$.

Wound healing can be separated into an early phase and later phase. The early events shortly after injury is comprised by an increase in the HA content of the wound $^{11,12}$, and latter events can be viewed as an extremely efficient type of wound healing. This appears to be a well defined sequence of events: a matrix rich in HA is laid down in then, cell-poor space, mesenchymal cell migration is stimulated, and the HA matrix is infiltrated by migrating cells from adjacent tissue. Cells within the HA matrix secrete both hyaluronidase, which degrades HA, glycosaminoglycans, and collagen, which concomitantly replace the HA as the matrix is remodeled ${ }^{13}$. The small HA fragments also stimulate phagocytic macrophages, which remove dead cell and older matrix components. This function is important because it allows cells proliferation and deposition of new matrix components to proceed efficiently.

Wound healing is a dynamic process involving both migration and repair. An inflammatory process with granulation

TABLE 1 - Grading values of healing wounds

\begin{tabular}{l|c|c|c|c|c}
\hline Variant & +1 & +2 & +3 & +4 & Factor \\
\hline Necrosis & & & & & -10 \\
\hline Abscess & & & & & -5 \\
\hline Neutrophils & & & & & -3 \\
\hline Lymphocytes & & & & & -3 \\
\hline Monocytes & & & & & +5 \\
\hline Granulation tissue & & & & & +5 \\
\hline Collagen & & & & & +25 \\
\hline Score & & & & & \\
\hline
\end{tabular}

\section{Results}

Purification and analysis of the acidic galactan

The different fractions were analysed by anthrone and protein $(280 \mathrm{~nm})$ (Figure 1). The extract from day 10 shows the presence of three peaks (I, II and III) eluted tissue synthesis, synthesis of collagen and remodeling of matrix characterizes the wound healing. This whole process is modulated biologically by active substances, produced by cells ${ }^{14}$.

\section{Methods}

Forty five Wistar rats (weighing on average $343,78 \pm 31,22 \mathrm{~g}$ ), were separated in three groups HA (hyaluronic acid), AG (acidic galactan) and $\mathrm{C}$ (control-saline solution) with $n=15$ each, and observed in individual cages. Anesthesia and antiseptic operative techniques were used for wound creation. An incision of $1,5 \mathrm{~cm}$ was made in the proximal intestine and HA $1 \%$, AG $1 \%$ or saline solution $0,9 \%$ was placed in the suture. After 05,10 and 21 days the animals were killed and a biopsy was taken from the scar tissue. Histopathologic methods were used to determine levels of necrosis, abscess, neutrophils, monocytes, lymphocytes, granulation tissue and collagen. After being stained with hematoxylin and eosin, sample were submitted for histological analysis and the data were transformed in scores and quantified in agreement with a modified score technique ${ }^{18}$ (Table 1). The Kruskall-Wallis nonparametric test was used to compare the treatment and control groups. $\mathrm{P}<0,05$ was defined as statistically significant. with water and $0.1 \mathrm{M} \mathrm{NaCl}$, and $0.2 \mathrm{M} \mathrm{NaCl}$, respectively, with a positive reaction for anthrone. The fractions of the peaks were subjected to agarose gel electrophoresis. The Peak I, eluted with water was a neutral galactan (no reaction with toluidine blue). Peak II contained the slowly moving component, and peak III showed a faster moving component (Figure 2).
The Peaks II and III were submitted to acid hydrolysis and the products observed on paper chromatography in two different solvents, showing that galactose is the principal representative of these polymers (Figure 3). Structural studies showed that the acidic galactans, with molecular weights estimated as 600,000 Da and 2,5 $\mathrm{x}$ $10^{6} \mathrm{Da}$ for Peaks I and II, respectively, are in accordance with ${ }^{8}$ (Figure 4).

This slowly moving component obtained from day 10 showed the presence of galactose. No uronic acid, sulfates, no proteins could be detected. This compound can be characterized as galactan -containing galactosamine with an acidic character, due to its positive electrophoretic migration and positive staining with toluidine blue ${ }^{8}$. The presence of pyruvic acid in the galactan of approximately $0,5 \%$, suggest an acidic nature and corresponds to a similar descript in the eggs of Pomacea lineata ${ }^{19}$.

In vivo investigation of wound healing: Peak II was used for the in vivo assay, since it has the approximately the same molecular mass as $\mathrm{AH}$.

Granulation tissue and inflammatory cells (neutrophils, monocytes and lymphocytes) were in great intensity $(+2,+3)$ the subgroup AG1. The score average of subgroup AG1 was $55,4 \pm 3,04$. It is significantly higher than of the subgroups $\mathrm{C} 1$ and $\mathrm{AH} 1$ which were, $43,4 \pm 18,92$ and 49,4 $\pm 10,78$, respective.

Ten days after surgery it was possible to observe a decrease of granulation tissue, with an increase in collagen fibers synthesis, as well as, a decrease of inflammatory cells and closing of vases. The appearance of giant cells and granulomas were observed with in AG2 group greatest intensity. The average score of the subgroup C2 was to $23,60 \pm 8,71$, significantly small than those of the subgroup AG2 and AH2, 30 $\pm 6,52$ and $27 \pm$ 12,55 respectively.

Twenty one days after surgery, the maturation of collagen fibers could be observed in all three subgroups. With significant presence of giant cells, unfixed granulomas and neovascularity in the subgroups AG3 and $\mathrm{AH} 3$ compared with $\mathrm{C} 3$.

The average score in the subgroup C3 was $30,4 \pm 17,31$, smaller than the averages of the subgroups AG3 and AH3, 50,6 $\pm 2,3$ and $69 \pm 12,24$ respectively (Table 2 ). 

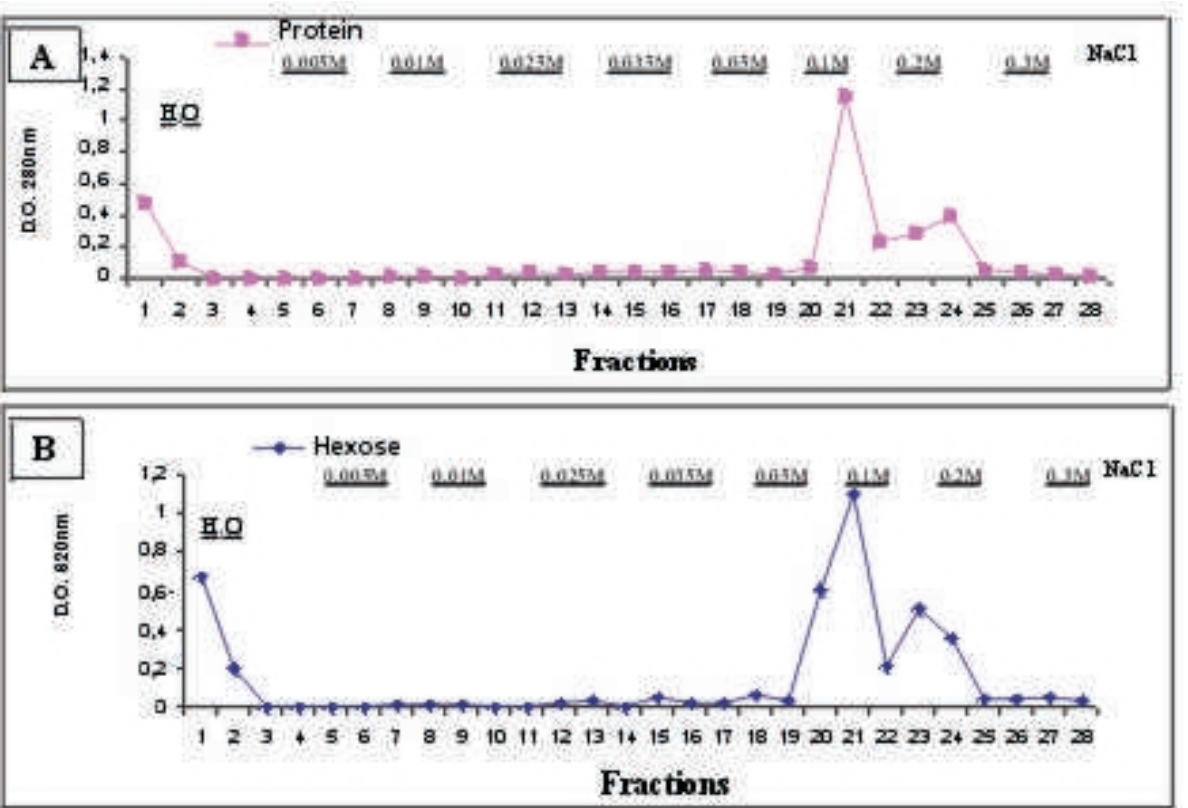

FIGURE 1 - $12 \mathrm{ml}$ of the fraction F80\%, obtained from roes of 10 was applied to a column of DEAEBiogel and elluted with 4 volumes of water and 3 volumes of increase concentrations of $\mathrm{NaCl}$. The quantification of proteins (A) was measured by the direct reading in the espectrophotomettry at $280 \mathrm{~nm}$ and the sugars (B) quantified by the anthrona reaction (Roe, 1955). Pick I: fractions in water, Pick II: fractions in $0,1 \mathrm{M} \mathrm{NaCl}$ and Pick III: fractions in $0,2 \mathrm{M} \mathrm{NaCl}$.
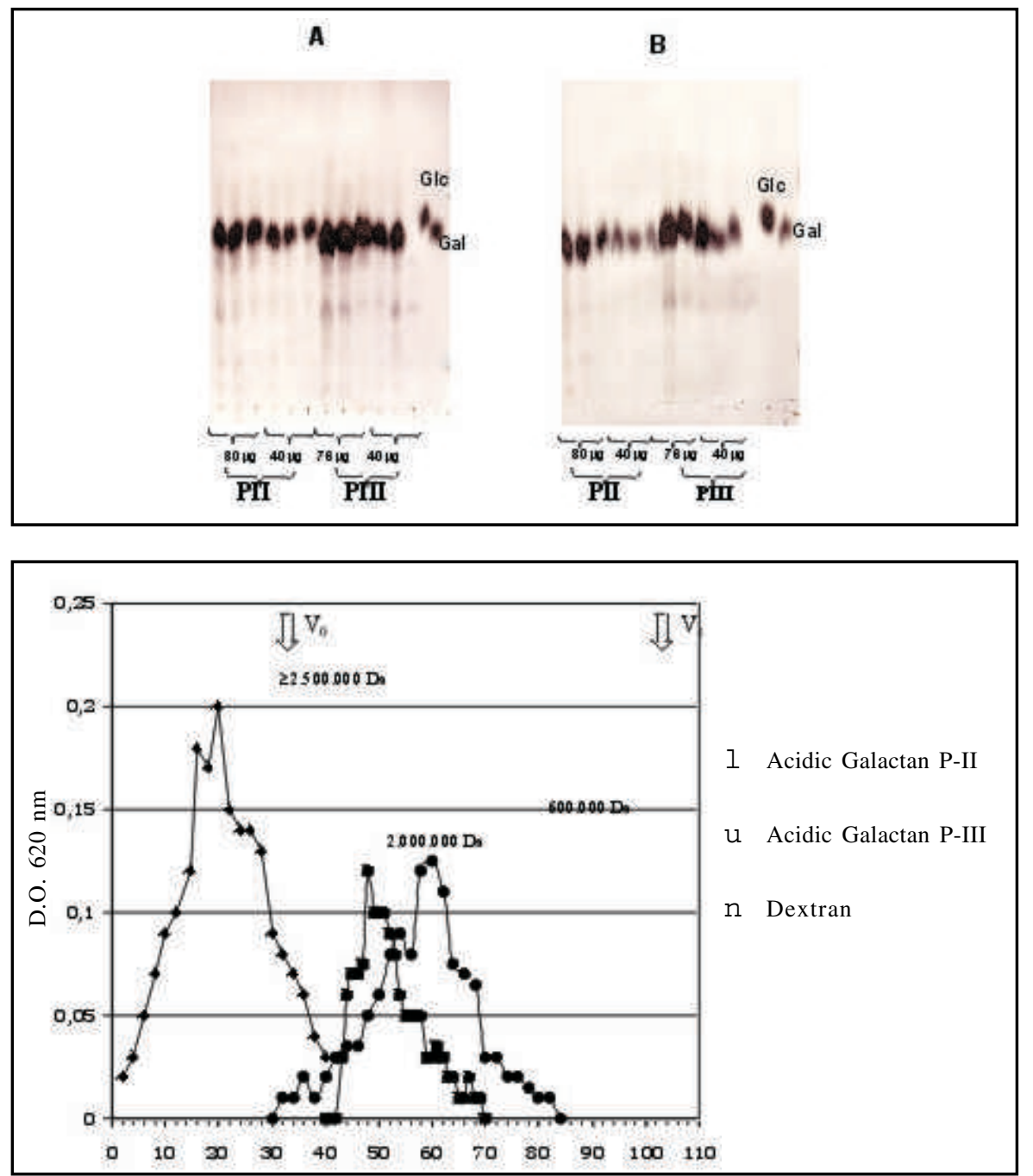

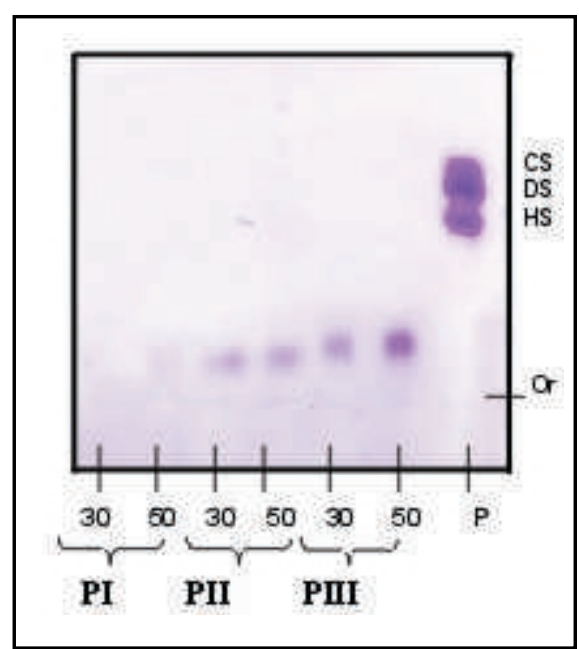

FIGURE 2 - Aliquots of $5 \mathrm{ml}$ (30mg and 50mg) of material corresponding to the neutral and acidic galactan were submitted to the agarose gel eletrophoretic in the buffer PDA (1,3 diaminopropanoacetato) $0.05 \mathrm{M} \mathrm{pH} 9.0$, visualized by reaction of toluidina blue, as described in methods, and discolored with buffer acetate of sodium, 0.02M, pH 5.0. Or.: origin, P: pattern containing chondroitin sulfate (CS), dermatan sulfate (DS) and heparan sulfate (HS)

FIGURE 3 - 80mg and 40mg of acidic galactan $\mathrm{P}-\mathrm{II}$, and $76 \mathrm{mg}$ and $40 \mathrm{mg}$ of acidic galactan $\mathrm{P}$ III were used, for hydrolysis with hydrochloric acid $2 \mathrm{~N}, 4 \mathrm{~N}$ and $8 \mathrm{~N}$. These volumes were placed in flasks, which were stamped separately and placed to $100{ }^{\circ} \mathrm{C}$ for 6 hours. After neutralization, the hidrolizeds were submitted to descending chromatographic in paper Whatman $\mathrm{n}^{\circ} 01$ for 16 hours in the solvents A and $\mathrm{B}$. The types of sugars were visualized by reaction of silver nitrate in half alkaline. Or.: origin, glucose Patterns (Glc) and galactose (Gal).

FIGURE 4 - Aliquots of $150 \mathrm{ml}(90 \mathrm{mg})$ of material corresponding to the acidic galactans, P-II and P-III were submitted to the chromatographic in column of Sepharose CL$4 \mathrm{~B}$, eluted in acid acetic $0.2 \mathrm{M}$. The fractions were quantified by the antrona method (D.O $620 \mathrm{~nm})$. Used Patterns: dextran $(2.000,000$, $147.000,40.000)$ 
TABLE 2 - Scores of the groups C, AG and HA, in the $5^{\text {th }}, 10^{\text {th }}$ and $21^{\text {th }}$ day of scar formad

\begin{tabular}{c|c|c|c}
\hline Days & Control & Acidic Galactan & Hyaluronic acid \\
\hline 05 & $43,4 \pm 18,92$ & $55,4 \pm 3,56$ & $49,4 \pm 10,78$ \\
\hline 10 & $47,6 \pm 16,50$ & $63 \pm 12,44$ & $50 \pm 14,74$ \\
\hline 21 & $30,4 \pm 17,31$ & $52,6 \pm 2,30$ & $69 \pm 12,24$ \\
\hline
\end{tabular}

\section{Discussion}

Several events occur during the embryonic development of Pomacea sp involving the acidic polysaccharides. The first noteworthy observation is the appearance of an acidic galactan wich reaches its maximum concentration around day 7 and completely disappears by day $12^{8}$.

The extract of the eggs of the Pomacea sp showed three fractions: a neutral galactan, and two acidic galactans. The acidic nature of these particular galactans seems to be due to presence of pyruvic acid. The molecular weights of the acidic galactans are approximately to $6-25 \times 10^{5} \mathrm{Da}$, and the amount of pyruvic acid present is approximately $1 \mathrm{~mol} / 100 \mathrm{~mol}$ of galactose in the molecule ${ }^{10}$.

This experimental model of scar formation was chosen because the process contains similar events of embryogenesis. HA was chosen as a reference molecule since several existing works have already characterized several functions in processes such as embryogenesis and healing. HA is associated with different cellular processes such as adhesion, aggregation, proliferation, inflammation, locomotion and migration, all important ones is the process of wound healing ${ }^{1}$.

HA was not found in the eggs of the mollusc Pomacea sp. The discovery that the AG is synthesized in the eggs of this mollusc during morphogenesis suggests that this compound is a substitute, in some functions for HA demonstrating strong parallelism between the events of the embryonic development of mammals and molluscs. It is possible that a similar acid as the acidic galactan, in the beginning of the morphogenesis, influences the migration of mesenquimal cells ${ }^{9}$.

HA is involved in the cellular proliferation of the embryogenesis, and its synthesis is necessary for proliferation of the fibroblasts ${ }^{2}$. Many studies also suggest the important participation of HA, in the modulation of deposition of collagen fibers, to main protein synthesized in the extracelular matrix and responsible for the formation of the scar ${ }^{20,21}$.

In the present work it was demonstrated, through histological analysis, that the level of organization of collagen fibers in the wall of the intestine, with HA and AG, was better than in control groups.

The HA and AG treated groups had a significantly high intensity of granulation tissue and neovascularity of the wounds when compared with the control group. This maybe is due to a better blood distribution, resulting in a smaller amount of tissue necrosis, ischemia, and stenosis. It is known that is in the later stages, of wound healing, that the stabilization of the matrix could result in a decrease in the amount of granulation tissue and neovascularization. These events were observed to be greater in group AG2, on the 10th day of healing, where there was already moderate deposition of collagen. In group AH2 the intestinal wall presented low deposition of collagen and persistence of the granulation, reaching an aspect similar to the group AG2 in the 21st days of experiment.

The results obtained in these experiments show several simillar properties between $\mathrm{HA}$ and $\mathrm{AG}$ in the involvement of these compounds in embryonic development and wound healing. This suggests that the mollusc Pomacea sp, produces the acidic galactan that participates on the molecular and cellular events during the embryonic development, similar to the role of HA in the mammals.

\section{Conclusions}

1. Exist three galactans populations in the development of the mollusc Pomacea sp: a neutral and two acidics.

2. Hystologic studies showed that during the wound healing, the group GA showed a good inflammatory answer, with synthesis of granulation tissue, formation of vassels and increase in the number of gigantic cells and granulomas, when compared to the groups control and HA. 3. The topical use of GA in intestinal wounds promoted the anticipation of events that are important in the wound healing.

\section{References}

1. Laurent TC, Fraser JRE. Hyaluronan. FASEB J 1992; 6: 2397-404.

2. Brecht M, Mauer U, Scholosser E, Prehm P Increased hyaluronate synthesis in required for fibroblast detachment and mitosis. Bioch J 1986; 239: 445-50.

3. Toole BP, Goldberg RL, Chi-Rosso G, Underhill CB, Orkin RW. Hyaluronate-cell interations, In: Trelstad R1, ed. The role of extracellular matrix in development. New York: Alan R Liss In.; 1984. p 43-66.

4. Jerônimo SMB. Glycosaminoglycan structure and content differ according to the origins of human tumors. Braz J Med Biol Res 1994; 27: 2253-8.

5. Raydell NW, Butler J, Balazs EAA. Hyaluronic acid is synovial fluid. VI. Effect of intra-articular injection of hyaluronic acid on the clinical symptons of arthritis in track horses. Acta Vet Scand 1970; 11:139-5.

6. Miller D, Stegmann R. Healon (sodium hyaluronate): guide to its use in ophthalmic surgery. New York: Wiley; 1983.

7. King SR, Hivkerson WL, Proctor KG. Beneficial actions of exogenous hyaluronic acid on wound healing. Surgery. 1991; 109: 76-84.

8. Nader HB, Oliveira FW, Jerônimo SMB, Chavante SF, Sampaio LO, Dietrich CP. Syncronized order of appearance of hyaluronic acid (or acidic galactan), chondroitin C-6 sulfate, chondroitin C-4/ C-6 sulfate, heparan sulfate, dermatan sulfate, heparin during morphogenesis, differentiation and development. Braz J Med Biol Res 1996; 29:1221-6.

9. Nader HB, Jerônimo SMB, Porcionatto MA, Dietrich CP. Biosynthesis of an acid galactan and sulfate glycosaminoglicans during embryonic development of the mollusc Pomacea sp. Bioch Biophys Acta $1985 ; 840: 187-92$.

10. Jerônimo SMB, Dietrich CP, Nader HB Struture of sulfated glycosaminoglicans synthetized during the ontogeny of the mollusc Pomacea sp. Comp Bioch Physiol 1989; 93B: 899-903.

11. Bentley JP. Rate of chondroitin formation in wound healing. Ann Surg 1967; 165: 89.

12. Bentley JP. Mucopolysaccharides synthesis in healing wound. In: Repair and Regeneration. (Dunphy, J.E. \& Van TMOC, Paiva JF, Medeiros MGL, Jerônimo SMB, Paiva VMP, Dietrich CP. Isolation and structural studies of heparan sulfates and chondroitin sulfates from three species of molluscs. J Biol Chem 1984; 259,1431-5. 
13. Spector J. Refinement of the coomassie blue method of protein qualification: a simple and linear spectrofotometric assay of 0.5 to 50 ?g of protein. Analyt Bioch 1978;.86: 142-6.

14. Roe JH. The determination of sugar in blood and spinal fluid with anthrone reagent. J Biol Chem 1955; 212: 335-43.

15. Dische Z. Color reactions of 6-deoxi and 3 6-dideoxioses. In: Whistler RL, Wolfrom M L. Methods in carbohydrate chemistry New York, Mosby, 1962.

16. Dische Z.. Color reactions of pentoses. In Whistler RL, Wolfrom ML. Methods in carbohydrate chemistry. New York, Mosby, 1962.

17. Nader HB, Dietrich CP. Determination of sulphate after chromatography and toluidine blue complex formation. Analyt Bioch 1977; 78, 112-8.

18. Myers AH, Postlethwait RW, Smith AG. Histologic grading of the experimental healing wound. Arch Surg 1961; 83:147-50.

19. Gorin PA, Spencer JF, Lindberg b, Linch F. Structure of the extracellular polysacharide from Corynebacteriuminsidiosum. Carbohydr Res, 1980; 79:131-5
20. Longaker M T, Adzick NS. Studies in fetal wound healing. Ann Surg 1989; 213: 292-6.

21. Steed DL. The role of growth factors in wound healing. Surg Clin North Am 1997; 77: $571-82$.

\section{Acknowledgements}

This work was supported by grants from CAPES and CNPq. We Thank Aldo da Cunha Medeiros and Maria Goretti Freire Carvalho for there help and support.

Cruz AKM, Pereira WO, Santos EA, Carvalho MGF, Medeiros AC, Oliveira FW. Estudo comparativo entre os efeitos do ácido hialurônico e do galactano acídico purificado dos ovos do molusco Pomacea sp na cicatrização de feridas. Acta Cir Bras [serial online] 2004 Jan-Fev;19(1). Disponível em URL: http://www.scielo.br/acb.

RESUMO - Objetivo: Comparar o efeito de ácido hialurônico (AH) e do GA na cicatrização de feridas intestinais. Métodos: O extrato semipurificado dos ovos do molusco foi obtido por fracionamento com sulfato de amônio e purificação por cromatografia de troca-iônica. Os galactanos obtidos foram eluídos em água (galactano neutro) e em 0.1 e $0.2 \mathrm{M}$ $\mathrm{NaCl}$ (galactanos acídicos). O estudo em vivo foi executado com 45 ratos Wistar, separados em três grupos $(\mathrm{n}=15)$. Soluções contendo AH 1\%, GA $1 \%$ ou solução salina $0,9 \%$, foram aplicadas topicamente nas suturas das feridas longitudinais localizadas no intestino delgado dos ratos. Depois de 05, 10 e 21 dias os animais foram sacrificados e biópsias dos tecidos cicatrizados foram realizadas. Resultados: A graduação histológica foi mais significante para os grupos do AH e GA quando comparado ao grupo C. O GA estimulou o aparecimento de macrófagos, células gigantes e aumentou a concentração de colágeno na área da ferida quando comparado ao AH. Conclusão: O uso tópico de GA em feridas intestinais promoveu a antecipação de eventos que são importantes na cicatrização de feridas.

DESCRITORES - Galactano acídico. Ácido hialurônico. Pomacea sp. Glicosaminoglicanos.

Correspondence:

Conflict of interest: none

Ana Katarina Menezes da Cruz

Financial source: none

Rua Mahatma Ghandi, 2401. Condomínio Ilha Verde/C 7/B

59150-000 Natal-RN

anakatarina1@uol.com.br

Data do recebimento: 13/10/2003

Data da revisão: 04/11/2003

Data da aprovação: 28/11/2003 